Disponível em

http://www.anpad.org.br/rac

RAC, Curitiba, v. 14, n. 3, art. 5,

pp. 478-494, Mai./Jun., 2010

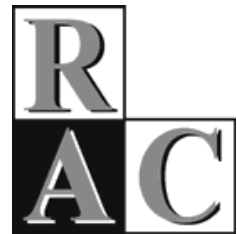

\title{
Fotografias de Família pela Ótica das Sucessoras: um Estudo sobre uma Organização Familiar
}

\author{
Family Snapshots through the Eyes of Successors: a Study of the Family Organization
}

Fernanda Tarabal Lopes * Mestre em Administração pela UFMG. Pesquisadora do NEOS - Núcleo de Estudos Organizacionais e Simbolismo.

Alexandre de Pádua Carrieri Doutor em Administração pela UFMG. Professor adjunto do CEPEAD/CAD/UFMG, Belo Horizonte/MG, Brasil.

* Endereço: Fernanda Tarabal Lopes Av. Antonio Carlos n. 6627, sala 4071, Bairro Pampulha, 31270-901, Belo Horizonte/MG. 31270-901. E-mail: fernandatarabal@hotmail.com

Copyright (C) 2010 RAC. Todos os direitos, inclusive de tradução, são reservados. É permitido citar parte de artigos sem autorização prévia desde que seja identificada a fonte. 


\section{RESUMO}

O estudo teve como objetivo analisar os vínculos estabelecidos entre o indivíduo e o trabalho na organização, que caracterizam sua permanência ou não na empresa da família. Para tanto foi realizado um estudo com as indicadas sucessoras de uma organização familiar. Através das histórias de vida dos sujeitos buscou-se compreender os vínculos estabelecidos entre as filhas que permanecem no negócio da família e a que abandona a empresa, por meio do entendimento do não-vínculo. A abordagem psicanalítica, aliada às teorias sobre o vínculo social, forneceu importantes contribuições para a análise do fenômeno em questão. Os resultados demonstraram que tanto a permanência como a saída do indivíduo da empresa não se relacionam apenas a questões organizacionais, mas também àquelas oriundas do âmbito familiar, de ordem psicológica. A emergência de tais questões demonstrou que os vínculos subjetivos e as relações psíquicas observadas entre os atores envolvidos estavam imbricados à racionalidade empresarial, que se configurou como reflexo de dramas vivenciados no espaço familiar. As análises tecidas no trabalho mostram a ponta de um iceberg, que tende a não ser considerado nas discussões sobre estas organizações.

Palavras-chave: organizações familiares; psicanálise; vínculo.

\section{ABSTRACT}

This study seeks to understand the link between the subject herself and her work at the organization, which characterizes whether or not to remain in the family business. Thus, a study has been conducted with the heiresses of family businesses. From their background we sought to understand the links established among those who remained in the family business and those who abandoned it, through the non-linkage understanding. The psychoanalytic approach and the theories of the social linkage provided important contributions to the analysis of the phenomenon in question. The results have shown that whether the heiress remains or leaves is not only related to organizational issues but also to the household environment and psychological questions. The emergence of these issues showed that the subjective link and the psychological relations observed were involved in the business logic, which was configured as a reflection of experiences in the family space. The analysis made in this work accounts for only the tip of the iceberg that tends not to be considered in discussions about this type of organization.

Key-words: family business; psychoanalysis; link. 


\section{INTRODUÇÃO}

Este trabalho aborda o tema das organizações familiares e tem como objetivo analisar os vínculos estabelecidos entre o indivíduo e o trabalho na organização, que ensejam a permanência, ou não, dos sujeitos indicados como sucessores na empresa da família. O diferencial deste estudo consiste no foco sobre as histórias das três herdeiras do fundador de uma empresa familiar, destacando a ótica destes sujeitos sobre as vivências narradas.

A proposta desta discussão justifica-se pelos aspectos particulares que permeiam as organizações familiares. Um destes aspectos refere-se à relação de família e negócio, e as possíveis repercussões que tal união pode acarretar para ambas as esferas. No ambiente da organização familiar mescla-se o papel profissional, racional e objetivo, com o papel familiar, indissolúvel, carregado de afetividade decorrente das respectivas histórias de vida. Este seria em destaque o traço singular dessa modalidade de organização: a onipresença de dimensões humanas influenciando o seu ritmo e lógica de funcionamento (Davel \& Colbari, 2003). Dessa forma, a dinâmica organizacional dessas empresas configura-se como indissociável das particularidades da instituição familiar, onde aspectos psicológicos/subjetivos relativos à família interferem cotidianamente na lógica das relações de trabalho.

Nessa perspectiva de estudos, um tema de destaque, refere-se à escolha e preparação de membros da família como possíveis sucessores, a fim de assumirem posições na organização, que são muitas vezes predeterminadas pela família. Tais sujeitos são incentivados desde a infância a se inserirem na lógica dos negócios familiares, representando papéis outorgados a eles, que podem ou não coadunar-se com suas próprias escolhas pessoais e profissionais. Nestes casos, observa-se que relações de poder relacionadas à família e/ou à organização são fatores importantes na construção das trajetórias de vida e profissão desses sujeitos, resultando em sua vinculação ou não à organização.

O estudo do vínculo dos sucessores com a organização pode evidenciar situações de assujeitamento (entendidas como situações de submissão, subordinação, conformação) do indivíduo aos padrões e normas da organização do trabalho na empresa (J. H. Faria, 25 de outubro de 2007), bem como ao papel outorgado outrora pela família. Por outro lado, a quebra dos vínculos do indivíduo com a organização, sendo esta imposta ao sujeito ou fruto de sua própria decisão, também deve ser compreendida, analisando-se em função de quais elementos são responsáveis pela desvinculação da pessoa.

Diante destas reflexões, o estudo dos vínculos desenvolvidos com o trabalho na organização, relacionados à permanência, ou não, de sujeitos indicados como sucessores na empresa familiar representa importante questão para os estudos organizacionais. Buscando analisar este tema, a investigação respaldou-se em uma abordagem psicanalítica; esta por meio de suas contribuições sobre o vínculo social, pôde trazer à tona importantes reflexões para a análise do fenômeno em questão.

Para a concretização empírica da pesquisa, realizou-se um estudo em uma organização familiar, onde foram (re)construídas as histórias de vida dos sujeitos membros da família envolvidos na organização: o pai e as três filhas sucessoras. O trabalho teve como orientação metodológica a pesquisa em histórias de vida. As histórias foram tratadas pela técnica de análise linguística do discurso, utilizada neste trabalho como ferramenta metodológica. Com base na análise do discurso, pode-se configurar categorias de análise temáticas, que perpassam por dois percursos semânticos: trabalho e família. As categorias compreendem: trajetória profissional e na empresa, gestão do pai na organização e relações familiares, que englobam aspectos da relação das filhas com o pai, das filhas com elas mesmas e do pai com as filhas. No final são traçadas algumas reflexões que apontam, dentre outras questões, a ponta de um iceberg que tende a não ser considerado nas discussões sobre estas organizações. 


\section{SUBJETIVIDADE, TRABALHO E VÍNCULO}

Na pauta de estudos sobre o trabalho, Clot (2006) enfatiza a necessidade do resgate da subjetividade e sua importância para o entendimento da atividade laboral, que deve ser compreendida como inerente ao desenvolvimento humano. Para a compreensão das relações do homem no trabalho, é importante, além da análise da organização, observar sua vida subjetiva. "A ação não é situada apenas nas circunstâncias presentes; é situada igualmente na história pessoal e social do sujeito psicológico e inclusive em seu corpo" (Clot, 2006, p. 199). As relações de trabalho devem ser analisadas tanto na situação real do ato laboral, como também na subjetividade relativa às histórias de vida dos sujeitos.

O trabalho pode ser palco de repetições vinculadas a vivências passadas, relacionadas a uma cadeia de significações pessoais, estando muitas vezes no campo do inconsciente. O inconsciente psíquico resulta da impossibilidade de uma atividade passar para outra. Dessa forma, uma representação passada não é abolida, e sim deslocada, permanecendo ativa. "Essas sequências psíquicas saturam a ação presente do condutor, imobilizando sua atividade” (Clot, 2006, p. 178). As situações passadas são ressignificadas no momento presente, o sujeito repete sua história, a fim de responder a uma situação atual.

Freitas (2000) destaca que as organizações são também lugares de transferência. Nestas, os indivíduos podem vivenciar relações novas e genuínas, mas podem também reatualizar seu repertório afetivo, resgatando motivações inconscientes, que possuem suporte em reminiscências de construções passadas. Nesse sentido, as organizações não criam as estruturas psíquicas, mas delas se utilizam. A autora afirma que tal relação é ainda mais destacada em empresas familiares:

Nas organizações, as pessoas disputam umas com as outras lugares, posições privilegiadas, poder e influência. Querem ocupar tronos que pertencem a outros, numa espécie de disputa semelhante à da criança que quer o lugar do pai ou de qualquer outro que lhe impeça o acesso ao objeto de amor, representado pela mãe. Isso é especialmente percebido nos casos de sucessão (e mais ainda na sucessão em empresas familiares), quando o filho, o discípulo ou o jovem destrona o "pai” e buscar instaurar uma nova ordem, mais moderna, mais dinâmica, e com maior potencial.... As empresas acabam se configurando como uma caixa de ressonância ampliada de desejos, capaz de absorver e estimular processos de transferência de afetos que antes ligaram o indivíduo ao pai, à mãe, aos irmãos, aos amigos e à comunidade pátria (Freitas, 2000, p. 45).

Nessa perspectiva, o resgate à subjetividade faz-se importante para a compreensão do trabalho. $\mathrm{O}$ controle das subjetividades dos indivíduos relaciona-se à sua vinculação, ou não, à organização. Desse modo, uma das formas de se exercer controle é por meio da formação e manutenção do vínculo entre indivíduo e organização. Tal controle é sutil, quase sempre imperceptível e se relaciona com os aspectos mais íntimos do indivíduo, como seus desejos, necessidade de pertença, de filiação, de realização. O vínculo se caracteriza como condição fundamental para a relação de troca entre organização e sujeitos; no entanto ele pode caracterizar-se, de acordo com a dinâmica exercida, "um meio eficaz de submeter e alienar o indivíduo à organização” (Faria \& Schmitt, 2007, p. 42).

Os autores acima enfatizam que os vínculos podem ser de duas naturezas: objetivo e subjetivo. $\mathrm{O}$ vínculo objetivo encontra-se nas relações formais de trabalho, como salário, contrato de trabalho etc. Já o vinculo subjetivo relaciona-se ao sentimento de pertença, filiação, possibilidade de realização de desejos, reconhecimento, entre outros (Faria \& Schmitt, 2007, p. 23). As formas de controle que operam no nível objetivo relacionam-se à formalização dos procedimentos das organizações e se explicam pela relação com a realidade instituída. Já no vínculo subjetivo possui caráter psicológico, que se caracteriza pela possibilidade de satisfazer necessidades psicológicas e obter satisfação por meio das relações sociais que se delineiam no interior da organização. Para Pagés, Bonetti e Gaulejac, (1987), o indivíduo se liga à organização por laços subjetivos, e não apenas por questões materiais e morais, vantagens econômicas e satisfações ideológicas. 
Sobre o vínculo social, Enriquez (1990) afirma que para compreendê-lo é necessário debruçar-se sobre os adventos da alteridade, ou seja, da concepção de um homem social, que interage e é interdependente de outros indivíduos. Para o autor, o vínculo social pode ser percebido como relação com os outros que se explica em termos de amor e ódio, aliança e competição, trabalho e lazer.

Sobre a origem do vínculo social, Freud (2006b) defende que este tem início na cumplicidade do crime comum. Da compreensão das civilizações primitivas e seus rituais totêmicos, Freud analisa o começo da organização social, das restrições morais e da religião. Para o autor, as mais antigas e importantes proibições estão ligadas aos tabus que correspondem às duas leis básicas do totemismo: não matar o animal totêmico e evitar relações sexuais com os membros do mesmo clã (proibição do incesto). Freud afirma que a base destes tabus se encontra na dimensão mítica: certo dia os irmãos que tinham sido expulsos retornaram juntos, mataram e devoraram o pai, colocando assim um fim à horda patriarcal. O pai primevo é violento e ciumento, guarda as fêmeas para si próprio e expulsa os filhos à medida que estes crescem. O pai, temido e invejado pelos filhos, é assassinado pelo desejo deles de obter o seu poder. No entanto os filhos também o amavam e o admiravam, o que faz com que sintam profundos sentimentos de culpa e remorso. Dessa forma, passam a proteger e venerar a imagem do pai, dando continuidade ao que era pregado por ele e que eles buscavam quebrar com seu assassinato. $\mathrm{O}$ pai morto tornou-se mais forte do que o fora vivo. O que até então era interditado pela presença real do pai continua sendo proibido pelos próprios filhos, procedimento psicológico conhecido na Psicanálise como obediência adiada. Desse sentimento de culpa filial nascem então os dois tabus fundamentais do totemismo com os quais a moralidade humana teve seu início: a lei que protege o animal totêmico (substituto do pai) e a proibição do incesto, que correspondem também aos dois desejos reprimidos do complexo de Édipo (Édipo matou o pai e casou-se com a mãe) e que marcam a ambivalência implícita na relação complexo-pai. No complexo de Édipo o menino apresenta desejos pela mãe, e tem no pai um rival. Caracteriza-se por sentimentos contraditórios de amor e hostilidade, pois a criança também ama a figura do pai que hostiliza. Já a menina é hostil à mãe, porque ela possui o pai, ao mesmo tempo quer se parecer com ela para competir e tem medo de perder o amor da mãe que é acolhedor. (Freud, 2006a).

Por meio das considerações psicanalíticas, Enriquez (1990) afirma que "a civilização nasce com e pela a repressão. Não pode existir corpo social sem a instauração de um sistema de repressão coletivo”. Para o autor, as formas de dominação são necessárias para que a ordem instituída não seja transgredida. Dessa forma, a abordagem do vínculo social, relaciona-se diretamente ao poder.

Nessa perspectiva, o autor discute as formas de dominação relacionadas ao vínculo social. Entre elas, cita-se a relação adulto/jovem, mais especificamente a relação pai/filho, e a ambivalência de sentimentos presentes nessa relação. A experiência primitiva do poder acontece na relação do filho com a figura do pai. Nessa relação define-se o que é bom e o que é ruim, o que é permitido e o que é proibido. O filho, dependente do pai, internaliza os interditos parentais ao longo do desenvolvimento de sua personalidade. O pai possui um papel de iniciador e de educador; ao ser o depositário da lei, transforma-se também em dominador potencial, possuindo direitos sobre a criança. O pai é apoiado a fazer com que o filho entre num ciclo de submissão-dominação; mas teme a revolta ou animosidade do futuro rival, que pode tomar-lhe o poder. Quantos pais martirizam cotidianamente seus filhos, os estropiam, os negam, ou simplesmente impedem-nos de viver e de se desenvolverem de maneira autônoma? Dessa forma, o pai pode desejar o desaparecimento do filho, assim como o filho pode desejar a anulação do pai, obstáculo à sua própria realização (Enriquez, 1990, 2007).

Observam-se também outros modos de controle social e vínculo, como aquele exercido pelo amor, pela identificação total dos sujeitos ou pela expressão de confiança. "Não há como falar de poder sem referência ao amor.... Todo poder usa desse artifício, tanto para se estabelecer quanto para durar" (Enriquez, 2007, p. 60). O discurso amoroso atua por duas formas de funcionamento, pelo fascínio e pela sedução. O fascínio está próximo da hipnose, corresponde à possibilidade que os homens têm de se perderem em um ser e de nele se encontrarem. É a forma de poder típica de Estados que vivem sob regimes ditatoriais ou totalitários. O ser que exerce fascínio sobre os demais se configura como um Deus, herói, profeta, sendo ao mesmo tempo um homem do povo, e um homem fora e acima do povo, induzindo nos indivíduos que o escutam a passividade e a docilidade. Já a sedução reside na aparência; 
o seduzido não se sente forçado, ele é atraído pelo discurso da sedução, pelas palavras lisas e sem asperezas, mesmo que estas não signifiquem coisa alguma. No entanto também na sedução há alienação. Ao jogar com o outro o sedutor busca amordaçá-lo, aliená-lo. Destaca-se que nessa tentativa há o risco de o sedutor ficar preso ao jogo que ele mesmo instituiu, ao contrário do fascinador, que não é nunca fascinado pelo outro.

Além disso, é importante se destacar também que as vítimas são ao mesmo tempo cúmplices de seus carrascos. O controle pelo amor cria nos sujeitos uma relação de dependência para com o objeto. Nessa posição de dependência, os sujeitos sentem necessidade de serem consolados, protegidos por uma autoridade tutelar, podendo ser facilmente manipulados e alienados. Neste estado de alienação em face do objeto, os indivíduos são constantemente reformados pelo desejo de auto-alienação. A autoalienação significa a fantasia de um estado não conflitual do psiquismo, uma coerência entre o que se pensa e o que se realiza e as exigências do mundo exterior. Dessa forma, os sujeitos mantêm o objeto idealizado, fonte de sua proteção.

Nesta perspectiva, cita-se também o vínculo afetivo estabelecido entre sujeito e organização, que se dá pela idéia do mito do herói fundador e do herói dirigente. O mito atua na organização desde a sua fundação, pela remissão à sua história oficial e ao seu passado - o mito fundante, e atua também pelo mito contemporâneo, na crença de que a organização é capaz de preencher todas as necessidades e desejos do indivíduo. O mito fundador é institucionalizado com o intuito de unificar pensamentos e comportamentos que convergirão em prol do projeto social comum, que será base de identificação, de relação afetiva com a organização, do vínculo social baseado na crença de pertença e no compartilhamento de sentimentos afetuosos entre os sujeitos. Dessa forma, a estratégia de mitificação atua como fonte de alienação, em que os indivíduos se sentem hipnotizados e se entregam aos ideais da empresa, tomando-os para si, sem questionamentos. O mito do herói fundador materializa-se nas fotografias, estátuas, bustos e demais imagens e narrativas relacionadas à história da organização e suas personagens. A história, muitas vezes, assemelha-se a um romance, como, por exemplo, do jovem humilde que muito batalhou e com brilhantismo conseguiu o sucesso empresarial. Também se destaca que esta tende a servir de guia para os sujeitos, buscando envolvê-los nos projetos da organização, mediante um comprometimento objetivo e subjetivo, "uma vinculação tão plena quanto possível”. As imagens refletem e reafirmam a história e valores da empresa, reforçando a figura mitológica do criador (Enriquez, 1997; Faria, 2004).

Os vínculos estabelecidos do sujeito com a organização estão relacionados com sua permanência ou saída dela. J. H. Faria (25 de outubro de 2007) discute tal situação em empresas familiares. Segundo o autor, é importante analisar em função de quais elementos de vínculo os indicados sucessores destas organizações decidem permanecer no negócio da família, sujeitando-se ${ }^{(1)}$ às suas normas e valores. A análise também deve ser feita com os sujeitos que saem, os expurgos organizacionais e familiares. Neste caso é importante verificar quais os elementos de não-vínculo estão relacionados ao expurgo, identificando se o que ocorre é um auto-expurgo do sujeito (relacionado a uma autopurificação) ou se ele foi expurgado pela organização por ser nocivo a esta.

\section{HISTÓRIAS DE VIDA}

O trabalho consistiu em um estudo de cunho qualitativo e teve como método de investigação a pesquisa em história de vida. Pelo resgate das histórias do sujeito buscou-se compreender os vínculos existentes entre os indivíduos e a organização. A história de vida tem como objetivo, "a partir da totalidade sintética que é o discurso específico de um indivíduo - reconstruir uma experiência humana vivida em grupo e de tendência universal” (Marre, 1991, p. 89). Consiste na busca de conhecimento, a partir da experiência do sujeito. É a maneira de recolocar o indivíduo no social e na história; inscrita entre a análise psicológica individual e dos sistemas socioculturais, a história de vida permite captar de que modo os indivíduos fazem a história e modelam sua sociedade, sendo também modelados por ela (Barros \& Silva, 2002). Sobre o uso da metodologia, esta pode configurar-se em depoimentos 
aprofundados, que buscam reconstituir a história do indivíduo desde a sua infância até os dias atuais; ou pode focar em experiências ou processos específicos que constituem desdobramentos dos depoimentos da história de vida, sendo mais sucintos e menos detalhados (Neves, 2002).

As histórias de vida compreendem o tempo recomposto pela memória (Gaulejac, Marquez, \& Ruiz, 2005). Dessa forma, o contar sua vida consiste no encadeamento de recontares, de modo que fantasia e realidade, objetividade e subjetividade, lembrança real e lembrança transformada se misturam, tornando dubitável o que é verdadeiro e o que falso, sendo tal distinção não passível de vir da narrativa ela mesma. No entanto, se convém diferenciar real e imaginário, não se pode perder de vista que o imaginário é também a realidade e que este abre para uma possibilidade de sentidos, de significações, de direções e de explicações. Além disso, o que se busca em relato de vida não é um espelho do social, mas como o indivíduo se apropria dele, projetando a sua subjetividade. Nesse sentido, ao pedir ao sujeito que conte a sua história, o que se busca é compreender o universo do qual ele faz parte, por mediação do seu ponto de vista, ou seja, da sua subjetividade em relação aos fatos sociais. Na história de vida, é o sujeito que ocupa o lugar central do que se conta (Barros \& Silva, 2002).

As histórias de vida foram coletadas por entrevistas semiestruturadas, que continham apenas o delineamento de uma trilha, onde constavam os objetivos de investigação, possibilitando que o informante falasse livremente. Os depoimentos dos entrevistados foram tratados por técnica de análise linguística do discurso, discutindo-se os achados com o conhecimento teórico referenciado. A análise do discurso, utilizada neste trabalho apenas como ferramenta de análise metodológica, configura-se como rica fonte de conhecimento dos fenômenos organizacionais (Carrieri \& Rodrigues, 2001).

Segundo Fiorin (2005), a linguagem veicula uma ideologia, uma visão de mundo; deve ser compreendida, a fim de depreender tais determinações ideológicas. Para tal compreensão, é fundamental o entendimento de duas dimensões: a interdiscursividade e da intradiscursividade. Todo o discurso é atravessado pela interdiscursividade, uma relação multiforme com outros discursos, em geral categorias de oposição. Para perceber o contexto interdiscursivo no qual o texto se insere, devese tomar como base o intradiscurso presente na narrativa, ou seja, a trajetória de sentidos que são desenvolvidos ao longo da narrativa, os percursos semânticos. Na percepção dos percursos semânticos, é importante desvelar os temas e figuras observados, bem como aspectos explícitos, implícitos e silenciados no decorrer do discurso, além das estratégias argumentativas da sintaxe discursiva. O entendimento dessas relações é importante para compreender o discurso em profundidade.

\section{ANÁLISE DAS HISTÓRIAS}

Para concretização empírica da pesquisa, realizou-se o estudo com uma organização familiar, localizada em município do interior de Minas Gerais. A empresa em estudo, referida neste trabalho como estamparia, foi fundada em 1969. Conta hoje com cerca de 70 funcionários, atuando principalmente na atividade de pintura eletrostática e industrialização de derivados de produtos siderúrgicos.

A organização passa por momento de transição, no qual o fundador, hoje com 66 anos, diz procurar desligar-se do cargo da presidência, voltando-se para o conselho administrativo. Sua sucessão está sendo preparada de modo que sua filha do meio assuma a função de presidente. A filha mais velha também trabalha na empresa, assumindo uma das diretorias. A mais nova encontra-se atualmente desligada da gestão da organização, sendo proprietária de estabelecimento de comércio.

As entrevistas foram realizadas com o fundador (atual presidente) e suas três filhas ${ }^{(2)}$ A filha mais velha, Amanda ${ }^{(3)}$,tem 41 anos e trabalha na empresa há 23 anos, sendo este seu único emprego. Este é o mesmo caso da filha do meio, Adriana, que possui 36 anos e há 20 anos trabalha na empresa. A mais nova, Aline, com 34 anos, permaneceu na empresa por 13 anos, até o seu afastamento em 2004. Todas 
as filhas, juntamente com o pai, José, são cotistas da empresa. A entrevista com o fundador possibilitou o conhecimento da organização, sua trajetória de vida e fundação da empresa, sendo importante para a compreensão da dinâmica organizacional e histórias das filhas e da família.

Os discursos dos entrevistados perpassam por dois percursos semânticos: trabalho e família; os percursos se encontram interlaçados muitas vezes por temáticas comuns. O percurso semântico do trabalho é marcado pelos temas da trajetória profissional dos entrevistados e de sua trajetória na empresa, e pelo tema da gestão do pai na organização da família. No percurso semântico da família, destaca-se a temática das relações familiares, que englobam aspectos da relação das filhas com o pai, das filhas com elas mesmas e do pai com as filhas.

\section{O Percurso Semântico do Trabalho}

No percurso semântico do trabalho, o tema da trajetória profissional das irmãs apresenta diversos pontos de convergência. Inicialmente cita-se a influência dos pais na escolha do curso superior. Os pais fizeram pressão para que as filhas estudassem um curso existente na cidade onde moravam, demonstrando facetas da experiência mais primitiva do poder, aquela que ocorre na relação pai-filho (Enriquez, 1990, 2007; Freud, 2006a, 2006b). O pai, em seu papel de iniciador e educador, define o que é bom e o que é ruim para o filho; ao ser o depositário da lei, transforma-se em dominador potencial, retirando do filho a capacidade de escolha. Devido a isso, por exemplo, Aline só foi cursar o que desejava, Administração, quando este curso abriu na cidade vizinha: "eu sempre amei o curso. Administração é tudo na minha vida”. A filha mais velha só atualmente pode estudar aquilo de que realmente gosta, devido à subordinação outrora apresentada em relação aos desejos dos pais. Hoje faz o curso de design de interiores; segundo ela "porque realmente é alguma coisa que eu gosto de fazer". No entanto, freqüenta o curso "só aos sábados, para não atrapalhar o andamento" da empresa. A relação de poder paterno se expressa desde a escolha profissional na juventude até sua relação com o curso atual, o qual é colocado num segundo patamar, sendo segundo ela, "levado em paralelo com a empresa”.

Sobre a entrada na empresa da família, todas as filhas tiveram sua primeira experiência profissional na organização, por volta dos 16 anos. No início, exerciam atividades mais simples, como atendimento de telefone, serviços de office-boy, dentre outros, passando em geral por todas as áreas da empresa, conforme iam satisfazendo as idealizações paternas sobre como se comportar e trabalhar na organização. Ressalta-se a entrada na organização como algo automático, natural, como inerente aos indivíduos que possuem negócio familiar, atuando como justificativa que mascara as relações desiguais. Tal comportamento relaciona-se ao mascaramento da luta pelo poder, que se dá pela justificação (a desigualdade é algo natural) ou pela negação (não há desigualdade de poder) (Enriquez, 2007). Apesar disso, observam-se na fala de Aline, indícios de uma conscientização de que a entrada na organização como algo automático não é fato tão natural, tendo em vista a metáfora utilizada pelo sujeito, cair de helicóptero na empresa, que remete a algo imposto às filhas, sem que houvesse um desejo anterior ou busca e planejamento para escolher este caminho.

\footnotetext{
“Nós três caímos lá dentro da empresa de helicóptero. Entendeu? Você nasceu naquela família, você cai lá dentro. Automaticamente, porque que você vai procurar emprego, porque que você vai trabalhar pra alguém, se você tem um negócio que é seu? Não vai! Nem pensa. É automaticamente, fez dezoito anos, na verdade foi dezesseis, cai lá dentro.” (Aline)
}

(sobre a entrada) "foi no susto, mas automaticamente, porque as pessoas assistem, a família tem alguma coisa automaticamente você vai trabalhar no negócio da família. E foi o que aconteceu comigo, foi praticamente automático, quando eu entrei foi praticamente automático.” (Amanda)

Em relação à trajetória de cada filha na empresa, as histórias divergem. A filha mais nova enfatiza o gosto pelo trabalho na organização. Relata que gostou do trabalho e daí não quis mais sair. Ela afirma sua tendência e gosto pela Administração como algo inato: "Você nasce desse jeito". Isto está enfatizado várias vezes na metáfora "está no sangue”, fato segundo ela herdado de seu pai: "a tendência administrativa do meu pai é toda minha”. O gosto pelo trabalho na empresa pode ser 
percebido como fator de transmissão familiar, como herança genética, mas também imaterial, simbólica, afetiva, que mantém forte ligação da filha com o pai (Carreteiro \& Freire, 2006). Sua predisposição e sua disposição para a gestão são, frequente e fervorosamente, enfatizadas em seu discurso, no qual se orgulha de feitos realizados em sua gestão que surtiram lucro para a empresa. Era, segundo ela mesma e as irmãs, a filha mais indicada a suceder o pai na organização, fato que não ocorre devido ao seu desligamento da empresa. A saída de Aline se dá devido a sérios conflitos em relação à gestão do pai, que acarretaram grandes frustrações e descontentamentos no trabalho. Segundo ela, tais conflitos começaram quando ela foi cursar Administração; afirma que o estudo pôs em cheque a admiração ora cultivada pelo pai. Daí surgiram consequências negativas não apenas na empresa, mas também no ambiente familiar.

A irmã do meio também afirma gostar do trabalho na organização. Atualmente ela passa por um período de transição na empresa, pois vem sendo preparada pelo pai para assumir seu lugar na sucessão. Com a saída da irmã mais nova, Adriana, encontra-se diante de um grande desafio: em curto período de tempo, tem de preparar-se para a transação, fato que lhe causa ansiedade.

Já a irmã mais velha mostra-se insatisfeita com o trabalho: "não morro de amores por Administração, não é a minha área, não sirvo para isso”. Diante de sua insatisfação, Amanda procura estar nos bastidores da organização, exercendo funções burocráticas e operacionais, ficando, segundo ela, "no meio do caminho", expressão que reforça sua inadaptabilidade à atividade profissional. Apesar de não gostar do trabalho, ela permanece na empresa sem motivação para assumir uma função gerencial e de liderança, nem galgar uma ascensão profissional na organização.

"Ela fala claramente que não gosta do trabalho na empresa; ela ta fazendo até terapia. Ela não gosta, ela chora, ela não quer. Tudo que pede para ela fazer ela xinga, ela reclama. Ela faz funções operacionais e aquela assim que não tem jeito mesmo. Ela não gosta, ela deixa claro, ela gosta de artes; Amanda nasceu para fazer... ela está fazendo agora no INAP, que não tem nada a ver: decoração. Mas é o que ela gosta. E a gente não pode atropelar, não sabe; ela já foi muito atropelada.” (Adriana)

Aline alega a estada da irmã na empresa ao comodismo e a um sentimento de incompetência para realizar outras atividades. Segundo ela, a permanência da irmã na organização ocorre pelo vínculo econômico: “a Amanda está lá pelo seguinte, porque ela já tem uma estabilidade financeira .... Ela só fica pelo lado financeiro". Ressalta que esta permanência no negócio da família se reflete em frustrações para a irmã, somado a outras não-realizações em outras esferas da vida: "Por que que a Amanda tem depressão direto? Porque ela nunca está satisfeita com o que ela faz. A Amanda está lá, ela não tem nada na vida dela que ela realizou”.

No entanto Aline ressalta que a irmã deveria "aprender a gostar": "Amanda, se dá dinheiro, se o negocio é seu, vai para um psicólogo, vai para um psiquiatra, quem você quiser, e exija de você aprender a gostar”. O discurso de Aline para com a irmã ressalta seu posicionamento a favor da subordinação e conformação dela aos padrões do trabalho na organização da família, ou seja, a sua sujeição, que dificulta possibilidades de auto-realização em outras atividades. Esse aspecto do discurso de Aline entra em oposição em relação ao seu posicionamento diante de seu próprio percurso na empresa, onde é defendida a necessidade de saída da realidade profissional tensa e conflituosa da organização familiar, tal qual ela fez.

A temática da gestão do pai é caracterizada como autoritária, marcada pela imposição de vontades, permeada de conflitos oriundos de relações de poder. O uso da metáfora, "ele tem que ter só índios e ele, o cacique” ressalta a afirmação. O autoritarismo é presente não apenas no relacionamento com as filhas no trabalho, mas no trato com os funcionários em geral, que demonstram sinais de resistência em relação à política do berro. Aline afirma que os conflitos, gerados pelo autoritarismo e imposição da vontade do pai, refletem a inabilidade dele em tratar as questões relacionadas à sucessão e à idéia de ser substituído por outra pessoa que pode fazer melhor ou tão bem feito quanto ele. As outras entrevistadas também afirmam o autoritarismo da gestão do pai.

As dificuldades de relacionamento com o pai no trabalho são enfatizadas nas escolhas lexicais: guerra, cacique, berro, grito, mandar, vigiar, brigar, xingar, ser tratada igual cachorro e falta de 
humildade, dentre outras. As características do pai/patrão enumeradas pelas filhas remetem à figura de liderança narcísica (Paes de Paula, 2003). A autora, baseada em estudo de Ket de Vries e Miller (1990), afirma que tal liderança é caracterizada por uma necessidade intensa de poder e prestígio, entre outras disposições narcisistas, necessitando explorar / subjugar o outro para satisfação de seus próprios desejos, descrição que se coaduna com o perfil do pai traçado pelas filhas.

Além disso, o relacionamento familiar é constantemente inserido no ambiente empresarial, o que constitui mais fonte de conflitos. No entanto as irmãs consideram a influência da vida afetiva na organização como algo inevitável, sendo difícil separar a esfera familiar da vivência empresarial. Em oposição ao discurso das filhas, o discurso do pai prega que tal inter-relação não acontece ou é evitada ao máximo para não ocorrer: "Coisa da empresa é coisa da empresa; família é família. A gente não deixa a coisa misturar de jeito nenhum”. O discurso do pai busca neutralizar a influência da família na organização, numa tentativa de exclusão do conflito, buscando em seu discurso transparecer a funcionalidade harmônica do sistema (Dahrendorf, 1980).

"Mistura sua cabeça tanto assim, o patrão e o pai, a punição do pai com o filho. Dá aquela misturada boa, você fica assim: "ele vai me chamar atenção” ... Porque o meu pai só me vê aqui como filha, então ele nunca vai... nunca consegue me enxergar aqui como profissional, e acontece a mesma coisa comigo. Ao invés de me chamar atenção em casa, ele chama minha atenção aqui, na frente. E isso todas as vezes causa um maior transtorno, uma maior dificuldade. Além de eu ter que trabalhar o meu profissional, ..., a gente tem sempre o desafio de estar provando que a gente pode ser, que a gente cresceu, eu amadureci, eu posso ser, ter, dar algum retorno, eu posso dar conta.” (Adriana)

O trabalho das filhas é tido como desvalorizado em relação ao trabalho de outros funcionários: "as pessoas de fora têm valor, mas as de casa não precisa pensar”. O não-pensar pode garantir ao pai o domínio do saber e a sustentação de seu poder perante as filhas. As políticas de gestão são mais duras em relação às filhas; por serem da família, devem trabalhar mais que os funcionários comuns; cita-se como exemplo a ausência de período de férias estendido. $\mathrm{O}$ trabalho na empresa, permeado por relações tensas e conflituosas, é tido, segundo relato das filhas, como fator de adoecimento psíquico, como stress ou depressão.

A gestão do pai e sua relação com Aline no trabalho culminaram em sua saída da empresa. Com enormes sentimentos de frustração e descontentamento em relação aos conflitos com o pai e sentindose "profundamente ferida", ela enfatiza o dia de sua saída da empresa como o mais feliz da sua vida. O desligamento da organização acarretou o distanciamento do pai, tanto no contexto empresarial quanto no contexto familiar. Parou de frequentar a empresa: "não passava nem mesmo na porta", como também parou de frequentar a casa do pai. Nesse contexto, o pai busca utilizar artifícios financeiros para puni-la, como em uma tentativa de reafirmar o controle de gestor/pai.

"Só que a forma como foi feita é que foi muito cruel. Ela ficou muito desgastada, ela ficou muito fragilizada, ela tinha acabado de se casar, de repente ela saiu da empresa perdeu tudo. Saiu com uma mão na frente outra atrás. Nem o salário que ela recebia aqui mais ela passou a receber. Foi uma forma que meu pai encontrou de punir a Aline, sabe. Então assim, foi cruel.” (Adriana)

Além disso, aspectos positivos em relação à gestão de seu pai também são mencionados. Cita-se o fato de o pai ter construído o patrimônio sem ter cursado educação superior, possuir tendência administrativa inata: "tudo que meu pai administrou até hoje foi por natureza. Está no sangue". Além de seu enorme conhecimento sobre a empresa, também se destaca o uso de lexemas como responsabilidade, seriedade, luta, esforço, que caracterizam aspectos positivos da gestão do pai e do empenho empregado por ele na fundação da organização. A exaltação do mito do herói fundador e do herói dirigente atua no imaginário dos sujeitos como instâncias de caráter mítico, funcionando como forma de controle. Nestes casos, o indivíduo passa a incorporar os ideais do fundador e da empresa, que irão unificar seu pensamento e seu comportamento (Faria, 2004). 


\section{O Percurso Semântico da Família}

Os conflitos mencionados no âmbito da empresa repercutiram nas relações familiares, caracterizando o segundo percurso semântico, observado no discurso dos sujeitos: o percurso semântico da família. Nele se destaca a temática das relações das filhas com o pai, das filhas com elas mesmas e do pai com as filhas. A saída da Aline da empresa abalou a estrutura familiar, como já mencionado, afastando do convívio do pai não apenas ela, mas as filhas em geral.

"Então no que a Aline afastou ficou eu e a Amanda, por um período assim no silêncio, no vazio. Só que a empresa agüentou, foi muito bem, mas a família estragou.... Aí a empresa subiu, mas a família acabou.” (Adriana)

Outra faceta de destaque da relação das filhas com o pai refere-se ao fato de ele não ter tido filhos homens. Segundo Amanda: "ele sempre quis ter um filho... E tudo mulher". Aline afirma que o pai sempre a tratou como homem, como o filho que não teve, delegando-lhe responsabilidades e autonomia que não foram repassadas para as outras filhas. Acredita que, devido a esse tratamento, pôde "engrenar" na carreira profissional. No entanto, sobre este fato diz: "para mim foi bom. Hoje eu já melhorei, já acho bom”. Ou seja, percebe-se implicitamente na sua fala que ela já achou ruim os desejos do pai em tratá-la como filho, fato este que pode contribuir em sentimentos conflituosos em relação à figura paterna.

A vontade de ter tido filhos relaciona-se, no percurso semântico do trabalho, ao desejo do pai de que fosse um homem o seu sucessor. Segundo o fundador, como "não veio o filho homem" e como o genro não apresentou interesses pelo trabalho na empresa, pois já possui negócio próprio, também familiar, restou-lhe aceitar a idéia de uma mulher na sucessão.

Aline aborda também a relação do pai com seu casamento. Após o casamento da filha, começou a exigir mais dela no trabalho, enfatizando que sua prioridade devia ser a empresa e não o marido. No entanto, a entrevistada ressalta que este discurso do pai entrou em contradição com o discurso pregado antes de ela se casar, discurso que defendia que "mulher nasceu foi pra acompanhar homem, ... que a prioridade, a partir do momento que você casa, a prioridade é o marido". Segundo ela, esse discurso tinha como finalidade o controle da sua mãe, no qual ele exige dedicação absoluta ao casamento. Dessa forma, o casamento de Aline é percebido pelo pai como perda de domínio sobre a filha, o que o faz mudar a idéia outrora defendida. O casamento é percebido pela filha como forte gerador dos conflitos decisivos para seu afastamento da empresa. Ao se casar, Aline quebra a relação primitiva do poder que acontece na relação do filho com a figura do pai (Freud, 2006b, Enriquez, 1990, 2007).

A história de Aline na organização familiar é marcada por relações conflituosas, muitas delas fruto de um relacionamento turbulento com o pai, que exibe consequências não apenas na vida empresarial, mas também na esfera familiar. Os conflitos vivenciados na trajetória profissional da empresa imprimem nela sentimentos negativos em relação à empresa familiar em geral.

“empresa familiar não é, não é coisa de Deus, não é. Só serve pra destruir. Na minha situação, só serviu pra destruir a nossa família, só, e pra impedir o crescimento da empresa.... a empresa familiar foi só frustração. Só frustração.... Então, sociedade, empresa familiar, vou te dizer o seguinte: em resumo, ela não pode existir, devia ser terminantemente proibido porque acaba com a vida das pessoas e da empresa.” (Aline)

No entanto, apesar da percepção negativa em relação à empresa familiar, ela acena à possibilidade de voltar para a empresa - "porque, se amanhã, se eu voltar para a empresa”, e também demonstra sentimentos positivos em relação à empresa, conforme vislumbrado no trecho que se segue.

"A empresa foi a menina dos meus olhos a vida toda.... Tudo meu foi pela empresa. Tudo meu foi focado para a empresa.... Me sentia 100\% realizada com a empresa. Amo. Amo aquele lugar. Se você perguntar pra mim se eu amo aquele lugar, eu ainda amo, mas no que diz respeito à empresa familiar foi só frustração. Só frustração.” (Aline)

Interessante ressaltar, na fala de Aline, que inicialmente ela expressa seus sentimentos em relação à empresa como algo no passado, expresso na escolha lexical: "foi”. Em seguida referencia-se à 
organização, usando o verbo no presente: “Amo. Amo aquele lugar”. Tal configuração de seu discurso leva a pensar sobre o real objeto a que se dirige o seu afeto; ao mudar o tempo verbal na oração, Aline muda também o objeto de referência: da empresa para o pai. Possivelmente é ao pai que Aline diz amar, no sentido presente do termo, figura deslocada para o substituto objeto empresa. O termo deslocamento, segundo a concepção psicanalítica, consiste na transferência de um elemento de forte conteúdo emocional, cuja presença na consciência seria desagradável, para outro objeto com que tem relação de proximidade, aparentemente sem problemas; dessa forma, ganha acesso à consciência, encontrando assim um substituto (Marcondes Filho, 2003). Outras análises são tecidas no item que se segue.

\section{CONSIDERAÇÕES SOBRE OS VÍNCULOS}

Pode-se inferir que o auto-expurgo de Aline da empresa familiar aparece mais como reflexo da relação conflituosa com o pai, fruto não só do ambiente de trabalho, mas de vivências turbulentas também no âmbito familiar. Seu auto-expurgo pode ser percebido por frustrações relativas ao conflito com a figura paterna (aspecto discursivo relevante em toda sua narrativa) e como forma de resistência em face do autoritarismo da figura pai/patrão, e não por uma inabilidade à função (J. H. Faria, 25 de outubro de 2007). Ou seja, seu afastamento relaciona-se a uma busca de uma não sujeição ao poder e controle do pai, e não à prática administrativa em si. Esta afirmação é corroborada nos lexemas escolhidos para expressar seus sentimentos em relação à empresa: realização e frustração.

Análises baseadas no referencial psicanalítico permitem inferir que o expurgo de Aline remete a uma possibilidade simbólica de matar o pai, buscando neutralizar o autoritarismo e poder relacionados à figura paterna. Essa possibilidade significa emancipar-se, sair da sombra do pai, afirmar sua identidade, por mais doloroso que tal ato possa configurar-se, identidade esta ora confundida com o próprio pai. Os relatos dos sujeitos demonstram a similaridade entre Aline e o pai: "ela é o meu pai de novo" (Adriana), o que reforça a busca de anulação que se destaca nessa relação. José projeta em Aline seus sonhos e frustrações, criando-a à imagem do filho homem que nunca veio. A projeção refere-se a um mecanismo de defesa da psique, no qual sentimentos internos pertencentes ao sujeito são atribuídos a um ser externo (Freud, 2006a). No entanto, no momento em que esta mais se assemelha à sua própria imagem, torna-se um rival, alguém que pode tomar-lhe o poder; uma filha criada à sua imagem, mas que detinha um conhecimento que ele não possuía e que questionava o saber de seu criador. Neste momento tem-se o auge dos conflitos, que culminam com a saída de Aline da empresa.

É importante ressaltar a completa negação de José a este fato, que racionaliza a relação numa tentativa de neutralização do conflito. A negação relaciona-se também a um mecanismo de defesa da psique, que serve como forma de exclusão da realidade, negando um fato que perturba o ego (Freud, 2006a). Ao negar o fato, o sujeito busca abrandar a realidade dolorosa da saída da filha da empresa, assim como os conflitos decorrentes. Em seu discurso enfatiza que os conflitos oriundos da relação família x empresa estão no âmbito econômico. Em geral, o que se analisa do discurso do pai é que este se anula, não relatando os fatos ora apresentados pelas filhas; ou ainda o pai anula as situações que lhe causam perturbação.

A ambivalência de sentimento: anulação x identificação na relação pai-filha é deslocada e reatualizada nas relações laborais e sentimentos de Aline em relação à empresa:

"É porque isso que eu to te dizendo, se for envolver administração, meu sentimento de quando eu lembro dela e só de frustração. Palavra que eu sintetizaria é frustração. Agora, a empresa, vou falar, pra mim ela é o lugar de maior prazer da minha vida, realização.... Tudo que eu penso na empresa, eu penso em realização. Eu estaria, profissionalmente, $100 \%$ feliz. Realização minha seria plena, mas questão da administração, frustração total. 100\% frustração. (Choro). Então acho que você pode resumir nessas duas palavras: realização e frustração.” (Aline) 
Já os motivos do vínculo de Adriana com a organização destacam as questões afetivas familiares. A entrevistada demonstra constantemente a necessidade em dar continuidade ao que o pai outrora construiu, assumindo para si as idéias defendidas por ele, incorporando os ideais do fundador e da empresa, que irão unificar seu pensamento e seu comportamento de modo a controlá-los (Faria, 2004). No entanto tal idéia é resgatada como algo positivo, como possibilidade de crescimento profissional. Dessa forma, a sujeição de Adriana à empresa e aos ideais do pai está relacionada à oportunidade vislumbrada por ela no negócio da família, que é tido como algo promissor, caracterizando também uma vinculação de caráter formal e objetivo, relacionada aos laços materiais, satisfações ideológicas e vantagens econômicas que também caracterizam formas de controle (Faria \& Schmitt, 2007).

"Eu peguei pronto, agora ele não. Cada tijolo que tem aqui tem uma história para contar. Então essa história dele, eu pego, eu guardo como se fosse minha, sabe. O sofrimento que ele teve, e as glórias, eu pego como se fosse minha... Não foi fácil, principalmente nesse caso a responsabilidade ela dobra, porque eu tenho que trabalhar e dar seguimento a tudo aquilo que ele construiu né. Já pensou, meu pai hoje com a idade que ele tem, 64 anos, de repente ele vê o negócio dele todo no chão por falta de alguém para acompanhar. Então, assim, eu abraço a causa dele, além de eu gostar, eu sei de tudo que ele passou, as histórias que ele conta.” (Adriana)

A incorporação dos ideais do pai por Adriana também pode estar relacionada ao projeto familiar comum. Ao dar continuidade à empresa, ela garante a continuidade dos próprios laços familiares, atribuindo união à família. "A empresa torna-se um importante símbolo da identidade familiar e a sua continuidade é um estímulo fundamental para a continuidade das relações familiares” (Lima, 1999, p. 92). O trabalho na empresa possibilita a apropriação do sonho do pai, reproduzindo os seus desejos, perpetuando os legados da família, o que a mantém unida à figura paterna. A própria empresa atua como objeto de transmissão familiar (Carreteiro \& Freire, 2006). Dessa forma, Adriana idealiza a figura do pai, reproduzindo os seus ideais. No entanto tal comportamento atua, na realidade, como reforçador da figura autoritária paterna, criando obstáculos à sucessão, tal como é afirmado pelas filhas, ao abordarem as dificuldades do pai em lidar com a passagem do bastão e delegação de poder.

Grzybovski, Boscarin e Migott (2002) afirmam que na gestão feminina de empresas familiares a mulher tende a conduzir a empresa como se fosse a sua família, como para cumprir a missão familiar e por se considerar a base desta instituição. No entanto, ao assumir tal papel, Adriana pode ter seus desejos e/ou sonhos pessoais rejeitados em detrimento dos sonhos e desejos empresariais e/ou paternos.

Possivelmente, Adriana repete nas organizações as situações vivenciadas outrora em sua história, a fim de responder à situação atual. Concebendo as organizações como local de transferência (Freitas, 2000), é como se Adriana reatualizasse seu repertório afetivo, construído em um pilar de submissão aos interesses paternos. Além disso, também é possível inferir que continuar o projeto do pai é uma forma de ser aceita por ele. Afinal, ela não era a filha criada como homem, a escolhida, como exposto no discurso dos sujeitos. Ao se dispor em continuar o legado do pai e abraçar sua causa, Adriana reatualiza o Édipo, que busca conquistar o pai, seduzi-lo, casar-se com ele (Marcondes Filho, 2003).

A rejeição de sonhos e desejos pessoais, em detrimento dos desejos empresariais paternos, é ainda mais evidente no caso de Amanda. A sujeição de Amanda à organização também mantém relações com questões familiares, fato reforçado na metáfora da empresa como família. Há que destacar que a entrevistada mantém-se há 23 anos numa atividade profissional na qual ela não possui predileção. Apesar da possibilidade de uma vinculação econômica mencionada pela irmã, Amanda atribui sua permanência na empresa à necessidade de ter que trabalhar no negócio da família e à impossibilidade de se realizar em outras áreas profissionais, devido ao controle dos pais. Seus desejos quanto a outras atividades profissionais são colocados em segundo plano, em comparação ao negócio familiar, no qual ela afirma não ter como sair. Além disso, a situação de subordinação que determina a sujeição de Amanda pode ser identificada com o poder, controle e autoritarismo da figura paterna mencionado por ela na narração de sua história.

Dentre as razões da sujeição de Amanda ao trabalho na empresa, ressalte-se uma possível carência afetiva do sujeito e necessidade de pertença, que se faz pelo trabalho na empresa. Cabe inferir que 
Amanda também reatualiza na empresa seu repertório afetivo, oriundo das relações tecidas em sua história de vida. Sua situação remete à experiência primitiva do poder, na qual o pai, em seu papel de educador, se transforma em dominador potencial, mantendo o controle sobre o filho num ciclo de submissão-dominação, impedindo-o de se desenvolver de maneira autônoma. Tal situação é também reforçada pelo controle social pelo amor e sua forma de indução à docilidade e à passividade (Enriquez, 2007). O amor ao pai e à família pode reforçar a necessidade de Amanda de sentir-se aceita, sentimento que acaba por criar no sujeito uma situação de dependência, dependência e carência que fazem com que o sujeito necessite ser protegido pela autoridade tutelar, no caso o pai. Tal relação encarna uma situação de submissão e alienação, alienação que caminha para um estado de autoalienação. Nessa situação o sujeito fantasia um estado não conflitual do psiquismo (Freud, 2006a). Manter-se nessa situação pode ser preferível a enfrentar os desejos recalcados e a não realização em outras esferas da vida - não tem como sair. Esta frase do sujeito representa não apenas uma impossibilidade de não trabalhar na empresa, mas a sua dificuldade em transformar sua própria vida.

"Eu digo o seguinte, porque hoje eu sou muito voltada pra área de artes, a minha praia é muito isso, eu gosto de mexer com decoração, mas eu não posso fugir daqui porque é uma coisa que é da família, não tem como sair." (Amanda)

Nesta investigação não houve abertura, por parte dos sujeitos, em realizar entrevistas com outros membros da família, como, por exemplo, a mãe, que não está entre aqueles que trabalham na empresa. Certamente tal possibilidade seria bastante oportuna e enriquecedora do trabalho. No entanto acreditase que este fato não constitui lacuna para o estudo, visto que o foco do trabalho era analisar o vínculo entre as sucessoras e a empresa, sendo o foco a visão das filhas, a compreensão das suas subjetividades em relação aos fatos sociais. Similar a um trabalho analítico, em que o que importa é a visão de mundo do sujeito e como ele apropria e cria significações de suas vivências. Dessa forma, o interesse neste trabalho não foi contrastar discursos para construir uma fotografia o mais próxima possível de algo concreto, visto justamente não se estar lidando com o concreto, mas com o sujeito psicológico. Neste trabalho, a visão das filhas sobre as suas próprias vidas é que ocupou o lugar central da análise. Dessa forma, a pesquisa esboça o que os sujeitos julgaram importante destacar.

A exemplo do comentado acima, destaca-se o silenciamento no discurso das filhas em relação à figura da mãe. $\mathrm{O}$ fato de a figura da mãe ter sido retomada com pouca expressão no discurso das herdeiras retrata o fato de que esta é uma figura pouco expressiva na trama familiar e mesmo nula na trama organizacional. A omissão da mãe é também revelada na descrição do casal genitor, assumindo o vocábulo nossos pais. Na mínima referência feita a ela pelos sujeitos percebe-se que esta teve sua importância na educação das filhas na socialização primária ao mundo feminino, dos afazeres domésticos, até a adolescência destas. Depois disso o pai as retira da casa (materna) e as insere na empresa (paterna), no mundo do trabalho (não-doméstico), ficando este o responsável pela socialização secundária (Berger, Luckmann, 1985).

\section{REFLEXÕES FINAIS}

A análise das histórias dos sujeitos aponta a influência do tecido familiar como determinante da trama empresarial, e vice-versa, o que vem enredando a trajetória das sucessoras e da própria organização. A influência da figura autoritária paterna e das relações familiares em geral pode ser percebida na entrada dos sujeitos na organização, sua permanência e saída, mostrando estar indissociável da dinâmica organizacional. Nesta perspectiva, os estudos organizacionais que se apóiam em abordagens psicológicas tornam-se valiosos para o estudo das organizações, em especial das organizações familiares. As abordagens sobre o vínculo social, preconizadas no trabalho (Enriquez, 1990, 2007; Faria, 2004; Faria \& Schmitt, 2007; Freud, 2006a, 2006b; Pagés et al., 1987), demonstram importantes aspectos subjetivos relacionados à vinculação, ou não, dos sujeitos com a empresa. A investigação parece sugerir que, para compreender as organizações familiares, é fundamental desprender-se apenas de análises pautadas na racionalidade positivista, voltando-se também para a compreensão da relação social. 
A emergência de questões psicológicas observadas aponta que os vínculos familiares e as relações psíquicas desenvolvidas entre os atores envolvidos estão imbricados à racionalidade empresarial. Neste sentido, tem-se a contribuição deste estudo. Por mediação de análises pautadas na Psicologia, o trabalho buscou contribuir para o debate sobre os conflitos que permeiam as organizações familiares. É fato que tais conflitos estão mais profundamente arraigados do que expõe a análise tecida aqui. Caberia certamente retomar com mais precisão outras vivências dos sujeitos, com destaque para aquelas experenciadas em suas infâncias. Tal empreitada demandaria uma disposição dos indivíduos de desejo e tempo em sujeitarem-se a uma profunda análise de suas vidas, fato que não foi possível neste trabalho de pesquisa. Tem-se aqui uma possibilidade para futuros estudos. Tal lacuna não compromete a iniciativa deste trabalho, que mostra a ponta de imenso iceberg que tende a não ser considerado nas discussões destas organizações.

É importante frisar a dificuldade em conseguir tais dados num trabalho de pesquisa. O sujeito tende a negar, como já comentado, as situações dolorosas, que lhe causam sofrimento. Em se tratando de empresários e do setting de pesquisa, tal dificuldade tende a ser ainda maior. Em geral, os sujeitos sentem-se confortáveis em expor seus sucessos, mas não os insucessos, fracassos e conflitos; afinal, falar para o outro é uma forma de admitir para si mesmo, e isto não é tarefa simples. Dessa forma, acreditamos que a proposta deste trabalho logrou pelo fato de apresentar os depoimentos e histórias em questão.

As relações observadas na empresa em análise remontam a conflitos psicológicos que moldam as trajetórias dos sujeitos na organização. No caso estudado, a filha mais indicada à sucessão sai da empresa; em contrapartida, a filha do meio, que não apresentava anteriormente perfil para assumir o lugar do pai, é empoderada como a atual indicada sucessora; por fim, tem-se a filha que declaradamente não gosta do trabalho, mas ainda assim permanece, afirmando não ter como sair. Tais fatos demonstram que a permanência/saída da empresa da família remonta a questões de afirmação de identidade, continuidade do laço familiar, dentre outras, que fogem por completo do que se espera da lógica empresarial. Dessa forma, reafirma-se a importância dessa discussão no âmbito dos estudos organizacionais.

Concluindo, destaca-se que os dramas familiares estavam imbricados às histórias dos sujeitos na organização. O trabalho mostrou-se, muitas vezes, palco de repetições vinculadas a vivências passadas, fato nem sempre consciente para os sujeitos. Situações outrora vivenciadas foram resignificadas no presente, histórias foram repetidas para responder ao momento atual. Nesse sentido, as histórias dos sujeitos na organização remetem a fotografias de família, fotografias múltiplas, que se revelam segundo a ótica e olhar do sujeito; mas permanecem arraigadas às situações de trabalho, determinando as trajetórias dos indivíduos na empresa e a trajetória da própria organização. Tais fotografias ora são camufladas pelos sujeitos, ora são escancaradas em sua mais nítida expressão. Dessa forma, a vivência organizacional configura-se como reflexo dos mais profundos dramas experenciados no espaço familiar: são fotografias de família estampadas na organização.

\section{Artigo recebido em 15.06.2008. Aprovado em 03.07.2009.}

\section{NOTAS}

\footnotetext{
${ }^{1}$ Segundo J. H. Faria (25 de outubro de 2007) a sujeição é uma forma de tornar o sujeito subjugado (submetido, subordinado, conformado) a algo, constituindo-se de parte da subjetividade desses sujeitos.

${ }^{2}$ Funcionários não-membros da família também foram entrevistados; no entanto suas histórias não constam nesse artigo, visto que não se enquadram nos objetivos dele. Para acesso ao trabalho completo, consultar: Lopes, F. T. (2008). Fotografia de família: histórias de poder em organizações familiares. Dissertação de Mestrado. Curso de Pós-graduação em Administração, Universidade Federal de Minas Gerais, Belo Horizonte, MG, Brasil.

${ }^{3}$ Nomes fictícios foram utilizados para todos os entrevistados.
} 


\section{REFERÊNCIAS BIBLIOGRÁFICAS}

Barros, V. A., \& Silva, L. R. (2002). A pesquisa em história de vida. In I. B. Goulart (Org.), Psicologia organizacional e do trabalho, teoria, pesquisa e temas correlatos. São Paulo: Casa do Psicólogo.

Berger, P. L., \& Luckmann, T. (1985). A construção social da realidade: tratado de sociologia do conhecimento. Petrópolis, RJ: Vozes.

Carreteiro, T. C., \& Freire, L. L. (2006). De mãe para filha: a transmissão familiar em questão. Psicologia clínica, 18(1), 179-191.

Carrieri, A. P., \& Rodrigues, S. B. (2001, setembro). As transformações nas significações culturais em uma empresa de telecomunicações: de empresa pública a filial privada. Anais do Encontro Nacional da Associação Nacional de Pós-Graduação e Pesquisa em Administração, Campinas, SP, Brasil, 25.

Clot, Y. (2006). A função psicológica do trabalho. Petrópolis, RJ: Vozes.

Dahrendorf, R. (1980). As funções dos conflitos sociais. Documentação e Atualização Política, (10), 29-36.

Davel, E., \& Colbari, A. (2003, setembro). Organizações familiares: desafios, provocações e contribuições para a pesquisa organizacional. Anais do Encontro Nacional da Associação Nacional de Pós-Graduação e Pesquisa em Administração, Atibaia, SP, Brasil, 27.

Enriquez, E. (1990). Da horda ao estado: psicanálise do vínculo social. Rio de Janeiro: Jorge Zahar Editor.

Enriquez, E. (1997). A organização em análise. Petrópolis: Vozes.

Enriquez, E. (2007). As figuras do poder. São Paulo: Via Lettera Editora e Livraria.

Faria, J. H. de (2004). Economia política do poder (Vol. 3). Curitiba, PR: Juruá.

Faria, J. H. de, \& Schmitt, E. C. (2007). Indivíduo, vínculo e subjetividade. In J. H. de Faria (Org.), Análise crítica das teorias e práticas organizacionais. São Paulo: Atlas.

Fiorin, J. L. (2005). Linguagem e ideologia. São Paulo: Editora Ática.

Freitas, M. E. (2000). A questão do imaginário e a fronteira entre a cultura organizacional e a psicanálise. In F. C. P. Motta \& M. E. Freitas (Orgs.), Vida psíquica e organização. Rio de Janeiro: Editora FGV.

Freud, S. (2006a). Conferências introdutórias sobre psicanálise (Vol.16, Parte III, Obras psicológicas completas de Sigmund Freud, 1915-1916.). Rio de Janeiro: Imago.

Freud, S. (2006b). Totem e tabu e outros trabalhos (Vol. 13, Obras psicológicas completas de Sigmund Freud, 1913-1914). Rio de Janeiro: Imago.

Gaulejac, V. de., Marquez, S. R., \& Ruiz, E. T. (2005). Historia de vida psicoanálisis y sociologia clínica. Mexico: Ediciones UAQ.

Grzybovski, D., Boscarin, R., \& Migott, A. M. B. (2002). Estilos femininos de gestão em empresas familiares gaúchas. Revista de Administração Contemporânea, 6(2), 185-207. 
Lima, A. P. (1999). Sócios e parentes: valores familiares e interesses econômicos nas grandes empresas familiares portuguesas. Etnográfica, 3(1), 87-112.

Marcondes, C., Filho (2003). A produção social da loucura. São Paulo: Paulus.

Marre, J. L. (1991). História de vida e método biográfico. Cadernos de Sociologia, 3(3), 89-141.

Neves, L. (2002, abril). Os desafios da história oral. Palestra proferida no I Encontro Estadual de História e III Encontro Nordeste de História Oral, Teresina, PI, Brasil.

Paes de Paula, A. P. (2003). Eros e narcisismo nas organizações. RAE-eletrônica, 2(2), 1-12. Recuperado em 12 fevereiro, 2008, de http://www16.fgv.br/rae/redirect.cfm?ID=1249

Pagés, M., Bonetti, M., \& Gaulejac, V. (1987). O poder das organizações. São Paulo: Atlas. 